\title{
THE COLLECTIVE TRADEMARK: INVITATION TO ABUSE
}

THE relatively recent statutory protection accorded collective trade and service marks encourages competitors to merchandise their products under a single trade emblem, ${ }^{1}$ and thereby threatens interference with both antitrust and traditional trademark policies. Ordinarily, the users of a collective trade or service mark are a limited group of competitors belonging to an association which owns and registers, but does not itself use, the mark. ${ }^{2}$ This type of mark was unprotected as such at cornmon law, ${ }^{3}$ because the right to exclude others from appropriating a trademark could be acquired only by its owner through previous use. ${ }^{4}$ Today, however, the Lanham Act grants the collective mark

1. Collective marks were first authorized by federal law in the Act of June 10, 1938, ch. 332,52 Stat. 638.

For discussions of collective marks, see 3 Callmann, Unfair Competition \& TradeMarks 1034-41 (2d ed. 1950) [hereinafter cited as Callarann] ; Amddur, Trade-Mark Law \& Practice 81-85 (Lanham Act ed. 1948) ; Robert, The New Trade-Mark Manual 6-7, 17, 4446 (1947) (written under her maiden name by Assistant Commissioner of Patents Daphne R. Leeds) [hereinafter cited as RoBERT] ; Hancock, Notes From the Patent Office, 47 TRADEMARK REP. 458 (1957).

Information on currently registered collective marks and their use was obtained for this Note in the Patent Office's Trademark Search Room, and through interviews with and questionnaires returned by several association-registrants. Information from these sources is cited as INTERVIEWS.

2. 'The term 'collective mark' means a trade-mark or service mark used by the members of a cooperative, an association or other collective group or organization and includes marks used to indicate membership in a union, an association or other organization." TradeMark Act of 1946 (Lanham Act) $\$ 45,60$ Stat. 444, 15 U.S.C. $\$ 1127$ (1952).

[C]ollective and certification marks, including indications of regional origin used in commerce, shall be registrable under this Act, in the same manner and with the same effect as are trade-marks, by persons ... exercising legitimate control over the use of the marks sought to be registered ... and when registered they shall be entitled to the protection provided herein in the case of trade-marks, except when used so as to represent falsely that the owner or a user thereof makes or sells the goods or performs the services on or in connection with which such mark is used.

60 Stat. 429 (1946), 15 U.S.C. $\$ 1054$ (1952).

Although the statute distinguishes between trademarks, which are used to identify and distinguish goods, 60 Stat. 443 (1946), 15 U.S.C. $\$ 1127$ (1952), and service marks, which are used to identify and distinguish services, ibid., this Note will use "trademark" to include both trade and service marks. Similarly, "goods" will denote services as well unless the context indicates otherwise.

3. Huber Baking Co. v. Stroehmann Bros. Co., 252 F.2d 945, 952 (2d Cir. 1958) (dictum). Because considered merely indicia of membership not warranting trademark protection, collective marks were not registrable prior to statutory authorization. Ex partc Foreningen Sveriges Spisbrodsfabrikanter, 6 U.S.P.Q. 27 (Comm'r of Patents 1930); accord, Feritage Furniture Inc. v. United Furniture Stores, 92 U.S.P.Q. 221 (Comm'r of Patents 1952). They were sometimes denied protection even by courts of equity. E.g., Weener v. Brayton, 152 Mass. 101, 104, 25 N.E. 46,47 (1890).

4. "It is use or appropriation . . that gives rise to an exclusive right to the mark." H.MH Publishing Co. v. Playboy Records, Inc., 161 F. Supp. 540, 542 (N.D. Ill. 1958); 
virtually the same status as a standard one. ${ }^{5}$ Underlying the act are the policies of safeguarding merchants who build up consumer good will through advertising and high-quality merchandise, ${ }^{6}$ and of enabling purchasers to identify desired products readily. ${ }^{7}$ Congress has also assumed that, because trademarks provide a means of distinguishing products, they stimulate producers to improve the quality of their goods and thus foster competition. ${ }^{8}$ Whatever the merit of this assumption in the context of standard trademarks, ${ }^{9}$ allowing a single, shared

accord, Columbia Mill Co. v. Alcorn, 150 U.S. 460, $463-64$ (1893) ; Neva-Wet Corp. of America v. Never Wet Processing Corp., 277 N.Y. 163, 172, 13 N.E.2d 755, $759-60$ (1938). Since a registrant-association does not itself use the collective mark, it could acquire no common-law trademark protection.

Unlike patents and copyrights, which are governmental grants based on a specific constitutional provision, U.S. Const. art. I, § \&; see Alfred Bell \& Co. v. Catalda Fine Arts, Inc., 191 F.2d 99, 100 (2d Cir. 1951) ; 1 SMIte, Patenr LAW at iii (1954); WittenBerg, LiterARY PROPERTY 77 (1957), trademark rights derive from the common law as part of the broader law of unfair competition, Jewel Tea Co. v. Kraus, 187 F.2d 278, 283 (7th Cir. 1950). Registration of a trademark is governmental recognition, not creation, of the right of protection against infringement. ROBERT 10. This right has been upheld by at least three centuries of case law. See Southern v. How, Poph. 143, 144, 79 Eng. Rep. 1243, 1244 (K.B. 1682). See generally Schechter, The Historical Foundations of the Law Relating To TrADE-Marks (1925).

5. 60 Stat. 429 (1946), 15 U.S.C. \$ 1054 (1952) (quoted at note 2 supra). [Hereinafter the act will be cited as Lanham Act; sections of the act will be cited as they appear in Statutes at Large, that is, without the United States Code section numbers, which can be found by adding 1050 to $\$ \S 1-22,1068$ to $\$ \S 23-28$, and 1082 to $\$ \S 29-45$.]

Among the goods and services currently merchandised under collective marks are bread, mink pelts, hotels, motels, restaurants, fishing tackle, home appliances, laundry and diaper services, cotton yarn, and the artificial insemination of cattle. INTERviEws.

6. Mishawaka Rubber \& Woolen Mfg. Co. v. S. S. Kresge Co., 316 U.S. 203, 205 (1942) ("The owner of a mark exploits this human propensity [to purchase goods by symbol] by making every effort to impregnate the atmosphere of the market with the drawing power of a congenial symbol.") ; S. REP. No. 1333, 79th Cong., 2d Sess. 3 (1946) [hereinafter cited as S. REP.] ("[W] here the owner of a trade-mark has spent energy, time and money in presenting to the public the product, he is protected in his investment from its misappropriation by pirates and cheats.") ; 92 CoNG. REc. 7872 (1946) (remarks of Senator O'Mahoney); 91 id. at 1724 (1945) (remarks of Congressman Lanham); 3 Callmann 975; 1 NIMs, Unfair Competition \& Trade-Marks $\$ 15$ (4th ed. 1947).

7. Mishawaka Rubber \& Woolen Mifg. Co. v. S. S. Kresge Co., supra note 6, at 205 ("[A] trade-mark is a merchandising short-cut which induces a purchaser to select what he wants, or what he has been led to believe he wants.") ; S. REP. 3 ("One [purpose] is to protect the public so it may be confident that, in purchasing a product bearing a particular trademark which it favorably knows, it will get the product which it asks for and wants to get."); 91 Cong. Rec. 1724 (1945) (remarks of Congressman Lanham) ; 3 Callarann 974; 1 NIMs, op. cit. supra note $6, \S 15$.

S. " $[N]$ o monopoly is involved in trade-mark protection. ... Trade-marks, indeed, are the essence of competition, because they make possible a choice between competing articles by enabling the buyer to distinguish one from the other. Trade-marks encourage the maintenance of quality by securing to the producer the benefits of the good reputation which excellence creates." S. REP. 3-4.

9. For the view that trademarks hinder competition because they create an inelastic market through artificial product differentiation, see ChaMrberLrn, THEORY of Monopolis- 
symbol to identify the goods or services of several producers can reduce competition in a given industry and prevent consumers from choosing preferred products.

Collective trademarks originated abroad among loose organizations of producers desiring to indicate the regional origin of their goods. ${ }^{10}$ Because these foreign marks were protected in the United States under international agreement, ${ }^{11}$ Congress made collective marks available to American producers "to put our citizens on a parity with the citizens and associations of foreign countries."12 Subsequently, the Lanham Act continued statutory protection for collective marks and, in addition, created the theretofore unrecognized certification mark - the only other registrable mark used solely by persons other than the registrant. ${ }^{13}$ Unlike the collective mark, the certification mark does not connote a particular source. ${ }^{14}$ It is generally used in addition to a trade name, and must be uniformly available to all producers whose goods or services meet the standards of certification. ${ }^{15}$ Since the certification mark may attest to, among other

tic Comppetition 59-63 (7th ed. 1956). Chamberlin advocates trademark infringement in order to "purify" competition. Id. at 270-74. For a similar analysis, see Brown, Advcrtising and the Public Interest: Legal Protection of Trade Symbols, 57 YaLE L.J. 1165 (1948).

10. Hearings on H.R. 102, H.R. 5461 and S. 895 Before the Subcommittee on TradeMarks of the House Committee on Patents, 77th Cong., 1st Sess. 94 (1941) [hereinafter cited as 1941 Hearings].

11. See Convention And Protocol With Other American Republics For The Protection Of Trade-Marks, February 20, 1929, art. 3, 6, 46 Stat. 2907, 2914, 2916-18, T.S. No. 833; Convention With Other Powers For The Protection Of Industrial Property Revising The Paris Convention of March 20, 1883, Revised At Brussels On December 14, 1900, At Washington On June 2, 1911 And At The Hague On November 6, 1925, June 2, 1934, art. 6,7 bis, 53 Stat. $1748,1756-57,1759-60$, T.S. No. 941.

12. See 83 Cong. Rec. 7244 (1938) (remarks of Senator McAdoo on the Act of June 10,1938 , stipra note 1). "It is the purpose of this bill to accord the same privilege to American industrialists which is now given under our laws to foreign industrialists ...." 83 CoNG. REc. 5862 (1938) (remarks of Congressman Lanham). "The only purpose of this bill is to right a wrong for the benefit of American businessmen, to give them a right foreign organizations have here but which our businessmen do not enjoy. That is all there is to this bill." Id. at 5863 (remarks of Congressman Sirovich).

13. A certification mark is authorized in Lanham Act $\S 4$ and defined in $\S 45$ as a mark used upon or in connection with the goods or services of persons other than the owner to certify regional or other origin, material, mode of manufacture, quality, accuracy or other characteristics. Certification marks originated in England in the early twentieth century. 1941 Hearings 95 . American case law had recognized the validity of a mark used for certification purposes prior to its federal registrability. See American Viscose Corp. v. Crown Craft, Inc., 28 F. Supp. 884 (S.D.N.Y. 1939). Moreover, marks which would taday be classified as certification marks were registered as collective marks under the 1938 Act. Letter from Daphne Leeds, Assistant Comm'r of Patents, to the Yale Law Journal, October 13,1958 , on file in Yale Law Library.

14. Amdur, Trade-Mark Law and Practice 76 (Lanham Act ed. 1948); 3 Callaiann 1039; Robert 8; Toularin, Trade-Mark Handeook \ 175 (1957); cf. Consolidated Dairy Prod. Co. v. Albers Milling Co., 104 U.S.P.Q. 407 (Comm'r of Patents 1955) (owner of certification mark may not certify his own goods.)

15. Unless the certification mark is available without discrimination, it may be cancelled at any time. Lanham Act $\$ 14(d)(1)$. 
things, a product's place of origin ${ }^{16}$-and thus enables domestic regional associations to prevent outsiders from appropriating distinctive geographical names - the Lanham Act rendered retention of the collective mark unnecessary. The statute's sponsors were, however, admittedly uncertain about the scope and significance of collective marks, ${ }^{17}$ and, rejecting this argument, ${ }^{18}$ incorporated them into the act. As a result, collective marks have been utilized not only by groups of regional producers ${ }^{19}$ but also by nonprofit fraternal and professional societies, ${ }^{20}$ and agricultural marketing organizations, ${ }^{21}$ as well as associations of otherwise independent competitors. ${ }^{22}$

Supplementing common-law rights, the Lanham Act extends substantial benefits to registrants whose marks are infringed or contested. ${ }^{23}$ Registration under

16. Lanham Act $\$ \S 4,45$. For marks certifying only regional origin, see, e.g., Registration No. 646222 of M1ay 28, 1957, "Dalmatian Sage Leaves" (used to certify that sage originated in Dalmatia); Registration No. 621022 of February 7, 1956, "Avery Island" (used to certify that salt originated on Avery Island, La.). 3 CaLLaran 1039 erroneously suggests that for a certification mark to certify only regional origin, its owner must be an association composed of all the regional producers.

17. See 1941 Hearings $95-96$.

18. Id. at 93-103. Mr. Wallace H. Martin, speaking for the Trademark Committee of the American Bar Association, argued for the abolition of collective marks on the ground that "a certification mark will do everything which a collective mark will do under the 1938 provision." Id. at 93, 94. Martin objected to the fact that the collective mark lacks a precise meaning. "I can find nobody who can tell me what a collective mark is." Id. at 95. "It will permit deception and ... the loose use of marks." Id. at 101. Martin eventually acquiesced in retaining the provision for collective marks, since the term was used in international conventions to which the United States was a party. See note 11 supra. But he insisted (in vain) that collective and certification marks be identically defined in substantially the same way that the Lanham Act defines the latter. Letter from Martin to Congressmen Kramer, Lanham, Plauché, Klein, Scott and Stevenson, November 17, 1941, in 1941 Hearings 232-33.

19. E.g., Registration No. 601116 of Jan. 18, 1955, "Select Barre Granite" (granite memorials) ; Registration No. 575703 of June 9, 1953, "Little Kanawha" (potatoes).

20. E.g., Registration No. 642727 of March 12, 1957, Mortgage Bankers Association of America; Registration No. 642444 of March 3, 1957, International Association of Lions' Clubs; Registration No. 636955 of Nov. 6, 1956, Theta Xi Fraternity; Registration No. 636954 of Nov. 6, 1956, Supreme Shrine of the Order of the White Shrine of Jerusalem, Ex parte Supreme Shrine of the Order of the White Shrine of Jerusalem, 109 U.S.P.Q. 248 (Comm'r of Patents 1956).

21. If such an association performs marketing services for its members but the goods are actually sold by them, a collective mark is properly registrable. If, however, the agricultural organization sells its members' goods and itself uses the mark to identify them, the mark would not be a collective one. See ROBERT 7. Examples of agricultural collective marks are Registration No. 534810 of Dec. 12, 1950, "Colt" (vegetables); Registration No. 504237 of Nov. 23, 1948, "Heart of California Brand" (beans).

22. Collective marks are also sometimes used along with the individual producer's trademark or trade name; ordinarily, the collective mark then takes the form of a "seal of approval." These seals, which seem to fulfill the function of certification marks, are occasionally used by members "on their honor." Other associations have extremely rigid testing requirements. INTERVIEWs.

23. For the continued importance of the common law, see S. C. Johnson \& Sons, Inc. v. Johnson, 175 F.2d 176, 178 (2d Cir. 1949) ("[A]lthough ... the act created rights uni- 
the act constitutes constructive notice of claim ${ }^{24}$ and prima facie evidence of prior use. ${ }^{25}$ Generally speaking, after five years, registration becomes incontestable ${ }^{26}$ and is transformed into conclusive evidence of the owner's exclusive right to the mark. ${ }^{27}$ Certain defects or offenses can bar such conclusiveness or result in a mark's cancellation, however. ${ }^{28}$

In addition, a certification mark may be cancelled if the registrant fails to control it, permits it to be used for noncertification purposes, refuses to authorize it for goods or services which meet the conditions of certification, or employs it in connection with the registrant's own products. ${ }^{29}$ In contrast, neither these nor any other special grounds for cancellation apply to collective marks. Furthermore, collective marks are not subject to the Lanham Act provision regulating

form throughout the Union ... it does not follow that, in determining what these are, we are not to be guided by the existing common-law ...."); HMH Publishing Co. v. Playboy Records, Inc., 161 F. Supp. 540,542 (N.D. I11. 1958) (continued common-law test of prior use) ; Ramirez \& Feraud Chili Co. v. Las Palmas Food Co., 146 F. Supp. 594, 604 (S.D. Cal. 1956) (Lanham Act's test for infringement is "in essence the common-law concept of unfair competition").

24. Lanham Act $\S 22$.

25. Lanham Act $\S \S 7(b), 33(a)$. While these sections speak of "ownership of the mark" and "exclusive right to use the mark", both depend upon prior use. Section 1 gives the "owner" of a mark the right of registration, but the Patent Office will deny registration absent a showing of its use. E.g., Ex parte Poirette Corsets, Inc., 115 U.S.P.Q. 356 (Comm'r of Patents 1957) ; Ex parte Glovecraft, Inc., 115 U.S.P.Q. 242 (Comm'r of Patents 1957).

26. Lanham Act $\S 15$.

27. Lanham Act $\$ 33(b)$.

28. Incontestability will not arise, or may be lost, for a number of reasons, including : abandonment; obtaining registration fraudulently; assignment of mark which misrepresents product's source; infringement of a mark or trade name continually used from a date prior to the registered mark's publication. Lanham Act $\$ 15$.

The certificate of registration ceases to constitute conclusive evidence if certain defects or defenses are established. Among them are: registration or incontestability fraudulently obtained; abandonment; misrepresentation of the product's source after an assignment; use of the registered mark to violate the antitrust laws. Lanham Act $\S 33(\mathrm{~b})$.

29. Lanham Act $\$ 14(\mathrm{~d})$. Furthermore, a certification mark having these defects will lose its incontestability. Lanham Act $\$ 15$. Congress was presumably aware of the inherent dangers in allowing marks to attest to the quality of many producers' goods and therefore provided these special safeguards. See United States v. Southern Pine Ass'n, 1940-43 Trade Cas. If 56007 (E.D. La. 1940) (consent decree) (highiy promoted and respected quality mark held to violate antitrust laws because available only to industry's largest producers). The Federal Trade Commission and "any person who believes that he is or will be damaged" may apply to cancel a certification mark under Lanham Act \$ 14.

Although collective marks have also been used to certify quality, INTERviews, the Lanham Act does not require that a collective-mark association permit nonmembers meeting the conditions of certification to use its mark. Thus, the prophylaxis against a certification mark being used to violate the antitrust laws (as in Southern Pine, supra) does not comprehend the abuse of a collective mark. See Breitenfeld, Collective Marks-Should They Be Abolished?, 47 TRADEMARK REP. 1 (1957) (collective marks permit evasion of special certification mark provisions). 
the joint exploitation of a trademark pursuant to a license agreement. ${ }^{30}$ The only restrictions on collective marks are, in fact, the statutory requirements that, as a condition of registration, the applicant have exercised "legitimate control" over the use of the mark, and that he not have utilized it to misrepresent the source of marked products. ${ }^{31}$ The ambiguity of these criteria, coupled with Congress' failure to provide special standards for the cancellation of collective marks, permits their users to engage in practices forbidden by the common law and the Lanham Act with respect to other trademarks.

The nearest analogy to the collective mark is found in the trademark-licensing agreement, which is subject to common-law and statutory safeguards designed to prevent the elimination of competition. Thus, licensor and licensee may not allocate the areas in which each will sell commonly marked goods, ${ }^{32}$ for such an allocation is tantamount to an agreement not to compete. ${ }^{33}$ Indeed, courts have held that the division of territory is, without more, illegal under the Sherman Act. ${ }^{34}$ Since Lanham Act benefits are only extended to licensed trademarks

30. Lanham Act $\$ 5$ allows "related companies" to use a common mark provided the use is "legitimate" and "does not deceive the public." Related-company status derives from the licensor-licensee relationship. Toulmin, Trade-Mark Handbook If 132 (1957); Shniderman, Trade-Mark Licensing: A Saga of Fantasy and Fact, 14 LAW \& ConTEarp. Prob. 248, 249 (1949). Lanham Act $\S 45$ defines a related company as "any person who legitimately controls or is controlled by the registrant or applicant for registration in respect to the nature and quality of the ... [marked product]." Quality control is the heart of a valid licensing agreement. Wehringer, Trademark Licenses: Control Provided, Control Exercised, 47 Tradearark Rep. 287 (1957); see 3 CallasanN 1041.; Robert 20-21.

31. Lanham Act $\$ 4$. Section 15 (incorporating $\$ 14(c)$ ) provides that a mark may be cancelled if registration was obtained contrary to $\S 4$, which permits the registration of collective (and certification) marks by persons "exercising legitimate control over the use of the marks" except when "used so as to represent falsely that the owner or a user thereof makes or sells the goods or performs the services on or in connection with which such mark is used." These restrictions have never been explained or litigated. If $\S 15$ is read literally, a mark, once properly registered, would not lose its incontestability even if later used contrary to the provisions of $\$ 4$.

32. Maola Ice Cream Co. v. Maola Milk \& Ice Cream Co., 238 N.C. 317, 77 S.E.2d 910 (1953) (common law) ; Timken Roller Bearing Co. v. United States, 341 U.S. 593 (1951) (Sherman Act); United States v. Bayer Co., 135 F. Supp. 65 (S.D.N.Y. 1955) (same) ; United States v. Holophane Co., 119 F. Supp. 114 (S.D. Ohio 1954), aff'd mem., 352 U.S. 903 (1956) (same).

33. See, e.g., United States v. Bayer Co., supra note 32, at 70.

34. E.g., Las Vegas Merchant Plumbers Ass'n v. United States, 210 F.2d 732, 741 (9th Cir.), cert. denied, 348 U.S. 817 (1954); Pennsylvania Water \& Power Co. v. Consolidated Gas, Elec. Light \& Power Co., 184 F.2d 552, 558 (4th Cir.), cert. denied, 340 U.S. 906 (1950) ; United States v. American Linen Supply Co., 141 F. Supp. 105, 115 (N.D. Ill. 1956). But see Timken Roller Bearing Co. v. United States, 341 U.S. 593, 605 (1951) (dissenting opinion) (Market allocation is not so "self-operating a category of Sherman Law violations as to dispense with analysis of the practical consequences of what on paper is a geographic division of territory."). At least one case has upheld an arrangement after finding it to be an allocation of marketing territories between competitors. United States v. National Football League, 116 F. Supp. 319 (E.D. Pa. 1953). 
which are "used legitimately,"35 and since this provision can be read to mean use consistent with the antitrust laws, ${ }^{36}$ the Lanham Act itself may proscribe market apportionment by licensor and licensee. In any event, the fact that a party to a license has violated the antitrust laws is at all times a defense to an infringement suit. ${ }^{37}$

An agreement allocating exclusive areas for employing a trade emblem is more likely to accompany a collective mark than a license. ${ }^{38}$ A licensor can simply refuse to permit the exploitation of his trademark by anyone likely to be a direct competitor. The members of an association, on the other hand, have little control over where a collective mark is used. Moreover, they have a greater incentive to divide the market, for the licensor will partially recoup sales lost to his licensee in the form of increased royalties. To date, only one case has passed on the division of territory under a collective mark-Huber Baking Co. v. Stroehmann Bros. $\mathrm{Co}^{39}$ There, one baker sued another and the association of which both were members ; plaintiff claimed that its contract with the association conferred the exclusive right to use the collective mark "Sunbeam" greater Philadelphia. The Second Circuit ruled that, because plaintiff's rights in the word "Sunbeam" antedated its membership in the association, and because plaintiff had an established position in the Philadelphia market, the contract served a "legitimate business purpose" and was not contrary to the public interest. $^{41}$ Presumably, however, the Sherman Act (and, perhaps, the Lanham

35. Lanham Act $\S 5$.

36. Shniderman, Trade-Mark Licensing: A Saga of Fantasy and Fact, 14 Law \& Contenrp. Prob. 248, 261 (1949), presents the view that "legitimate use" was put into $\$ 5$ for antitrust purposes. On the other hand, Assistant Commissioner of Patents Leeds "know[s] of no authority" for the assumption that use of the word "legitimately" in $\$ 5$ means that a mark cannot be used to violate the antitrust laws, but adds that "legitimately" means "lawful in all respects." Letter from Daphne R. Leeds to the Yale Law Journal, November 13, 1958, on file in Yale Law Library.

37. Lanham Act $\S 33(\mathrm{~b})(7)$. Two unsuccessful bills would have deleted this provision. S. 1957, 82d Cong., 1st Sess. (1951) ; S. 2540, 83d Cong., 2d Sess. (1954). Of the former, Senator Wiley stated: "The bill will eliminate the inequitable defense in an infringement proceeding of past or present violation of the antitrust laws, since public and private remedies for antitrust violations lie under other acts and do not properly form a part of a trade-mark act." 97 CoNG. REC. 9469 (1.951). The report accompanying the second bill states, however, that the proposed deletion of $\S 33(\mathrm{~b})(7)$ was "not intended to deprive any person of the defense of unclean hands but is done only because such defense is deemed available." S. REP. No. 2266, 83d Cong., 2 d Sess. 9 (1954).

38. In at least one association, a member who in any manner enters the territory of a fellow member forfeits his right to use the collective mark anywhere. INTERviews.

39. 252 F.2d 945 (2d Cir. 1958).

40. The registered collective mark actually consists of a representation of a little girl eating a slice of buttered bread. Registration No. 401161 of April 27, 1943, republished March 14, 1950. The girl is referred to in the trade as "Miss Sunbeam," 252 F.2d at 949, and the court and the parties regarded her, the word "Sunbeam" and the entire "Sunbeam campaign" as inseparable, $i d$. at 957.

41. Id. at 956-57. The court's test of "legitimate business purpose" is borrowed from a line of trademark cases upholding contracts dividing the use of a mark among various 
Act) forbids geographic apportionment under a collective mark in all other situations. ${ }^{42}$

Even absent an express division of territory, the adoption of a collective mark by an association may result in the elimination of competition among its members. ${ }^{43}$ A given member will prefer. to expand into virgin territory rather than invite retaliation by entering a market where another member is already using the mark. Besides, expansion into the latter's bailiwick may be difficult : if he adequately services his customers, they will have little incentive to change suppliers. The invading member may also be subjected to an unfair competition suit, as in $H u b e r$, and, possibly, restrained from trading on the good will of the established member. ${ }^{44}$ Should the former copy nontrademark features of the established member's merchandising in order to obtain maximum advantages from pre-existing good will, he would clearly be guilty of unfair competition. ${ }^{45}$ Although, theoretically, he could expand under a second trademark, the added advertising expenses might prove prohibitive, and intricate distribution problems could attend the special labeling and packaging of a product in accordance with its destination. ${ }^{46}$

products. E.g., Chester H. Roth, Inc. v. Esquire, Inc., 186 F.2d 11 (2d Cir.), cert. denied, 341. U.S. 921 (1951) (Esquire socks and Esquire Magazine) ; California Fruit Growers Exchange v. Windsor Beverages, Ltd., 118 F.2d 149, 151 (7th Cir. 1941) (Sunkist fruit and Sun-kist soft drinks). Contra, Campbell Soup Co. v. Armour \& Co., 81 F. Supp. 114, 119 (E.D. Pa. 1948), aff'd, 175 F.2d 795 (3d Cir.), cert. dcnied, 338 U.S. 847 (1949) (red and white label on soup and milk). "Legitimate business purpose" apparently provides a standard for measuring anticompetitive effect similar to that found in the "rule of reason" announced in Standard Oil Co. v. United States, 221 U.S. 1, 58 (1911).

42. See Toulain, Trade-Mark Handbook f 242 (1957) (collective mark may not be used to violate antitrust laws) ; notes 32-36 supra and accompanying text.

In the improbable situation of all participants having geographically limited, pre-existing rights in the mark, each would, in all likelihood, take advantage of Lanham Act $\$ 2$ (d)'s provision for concurrent registration, rather than adopt a collective mark. That section allows such registration when marks are lawfully used concurrently at common law. See Hanover Star Milling Co. v. Metcalf, 240 U.S. 403 (1916) ; Tillman \& Bendel, Inc. v. California Packing Corp., 63 F.2d 498 (9th Cir. 1933).

43. The following discussion assumes that, as in the Huber case, the collective mark is dominant. "[T]here is no question as to the similarity of the Sunbeam wrappers and labels used by Stroehmann and Huber in Philadelphia. That such similarity would cause confusion in the minds of customers is not disputed." 252 F.2d at 951.

44. In Hubcr, the Second Circuit appeared impressed by the facts that plaintiff had served the Philadelphia area for several years previously, and that Philadelphians may well have associated the contested mark with plaintiff's bread. $I d$. at 955-57. In such a situation, the classic "passing off" doctrine, see note 55 infra and accompanying text, may be invoked in plaintiff's favor.

45. Tas-T-Nut Co. v. Variety Nut \& Date Co., 245 F.2d 3 (6th Cir. 1957) (copying color and ornamental design of nut package illegal) ; Moxie Co. v. Daoust, 206 Fed. 434 (1st Cir. 1913) (copying beverage's color and taste, bottle's size and shape); Wm. Wrigley, Jr., Co. v. Colker, 245 Fed. 907, 909 (E.D. Ky. 1914) (coloring and marking of gum wrappers) ; H. A. Metz Labs., Inc. v. Blackman, 153 Misc. 171, 275 N.Y. Supp. 407 (Sup. Ct. 1934) (alternative holding) (pink label on drug).

46. Timberg, Trade-Marks, Monopoly, and The Restraint of Competition, 14 LAW \& 
The second potential abuse inherent in sharing a mark-the identical marking of dissimilar products-is also proscribed in the case of a license. ${ }^{47}$ The common law requires that the licensor control the quality of the licensee's marked goods ${ }^{48}$ or forfeit his right to restrain infringement. Forfeiture has been grounded on either the theory that the mark no longer identifies a particular product, ${ }^{49}$ or that it has been used to work a fraud on the consumer. ${ }^{50}$ Adopting the common-law doctrine, the Lanham Act provides that, if two or more companies use a mark pursuant to a license agreement, they cannot register it unless the licensor controls the nature and quality of their goods. ${ }^{51}$

In sharp contrast, the act does not require the users of a collective mark to sell a product of standard quality. ${ }^{52}$ They thus can offer goods of varying characteristics in the same market. If they do, the consumer, unable to discriminate among competing products, will be as uncertain that he is purchasing what "he wants ... or has been led to believe he wants" 53 as he would be if attempting to choose rationally among items sold in plain white wrappers. ${ }^{54}$ For the same reason, an

Contemp. Prob. 323, 335 (1949); Developments in the Law-Trade-Marks and Unfair Competition, 68 HaRv. L. Rev. 814, 900 (1955).

47. See generally Wehringer, Trademark Licenses: Control Provided, Control Exercised, 47 Trademark Rep. 287 (1957).

48. Arthur Murray, Inc. v. Horst, 110 F. Supp. 678 (D. Mass. 1953) ; E. I. du Pont de Nemours \& Co. v. Celanese Corp. of America, 35 C.C.P.A. (Patents) 1061, 167 F.2d 484 (1948).

49. "[T] $]$ he use of the plaintiff's trade-name by the many local [independent] offices, under the sanction of contracts made by the plaintiff assuming to license the use of the trade-name, has caused the name to lose its distinctiveness as the trade-name of the plaintiff." Everett O. Fisk \& Co. v. Fisk Teachers' Agency, Inc., 3 F.2d 7, 9 (8th Cir. 1924).

50. "When the plaintiff permitted [a third party] ... to use its trade-mark 'May-Bud" on cheese manufactured by others, the identity of whom it had no knowledge, it was party to a fraud committed against the public, and as a result it now is in no position to invoke the aid of a court of equity to protect that trade-mark." Purity Cheese Co. v. Frank Ryser Co., 57 F. Supp. 102 (E.D. Wis. 1944) ; accord, Broeg v. Duchaine, 319 Mass. 711, 67 N.E.2d 466 (1946).

51. Lanham Act $\$ \$ 5,45$.

52. Lanham Act $\$ 4$ provides simply that, to obtain registration, a collective-mark association must exercise "legitimate control over the use of the mark." It does not require the association to maintain quality control. Letter from Daphne R. Leeds, Assistant Commissioner of Patents, to the Yale Law Joumal, Nov. 13, 1958, on file in Yale Law Library. Commissioner Leeds' interpretation of this provision has changed. See Ropert 45. Compare Huber Baking Co. v. Stroehmann Bros. Co., 110 U.S.P.Q. 349 (S.D.N.Y. 1956) (oral opinion), rev'd on other grounds, 252 F.2d 945 (2d Cir. 1958). Presently, "control over the use of the mark" appears to mean no more than that the association bring action against an infringer. $3 \mathrm{C}_{\text {ALLMAaNN }}$ 1040. Although many registrants of collective marks control the quality of their members' products, such control often consists merely of imposing relatively low minimum standards which admit of significant variations. INTERvews.

53. See Mishawaka Rubber \& Woolen Mfg. Co. v. S. S. Kresge Co., 316 U.S. 203, 205 (1942).

54. The argument assumes that the buyer is the ultimate consumer and not a middleman. Those purchasers who buy the commonly marked product directly from the producer would know the product's source of origin. 
opportunistic producer could exploit the reputation of another association member by entering the latter's market with an inferior product. Although "passing off" goods as someone else's is the classical form of unfair competition, ${ }^{55}$ and although the Lanham Act proscribes trademark infringements which constitute "passing off," remedy against a substandard co-user of the mark. The former would probably be found to have acquiesced in this sort of "passing off" when he agreed to market his goods under a shared trade symbol..$^{57}$ In effect, therefore, the collective mark is an agreement to pool good (or ill) will.

By allowing competitors to merchandise their products in the same market under identical indicia of origin, the collective mark also discourages product competition. ${ }^{68}$ True, Congress felt that trademark protection, "securing to the producer the benefits of the good reputation which excellence creates," would promote higher merchandising standards. ${ }^{59}$ But each user of a collective mark in a given area lacks assurance that the consumer will reorder his goods because of their quality; consequently, no incentive exists to improve customer appeal. This inability to reap the rewards of excellence can induce the members of a collective-mark association to standardize their products and, hence, to abolish product competition among them. Although product standardization may in some instances stimulate price competition, ${ }^{\text {co }}$ its tendency, when identical products are sold under the same mark, is to eliminate all competition between the participants. ${ }^{61}$

The collective mark places additional restraints on competition by enabling

55. 1 Nims, Unfair Codrpetition \& Trade-Marks $\$ 9 a$ (4th ed. 1947); see, e.g., Howe Scale Co. v. Wyckoff, Seamans \& Benedict, 198 U.S. 118, 140 (1905); Goodyear's India Rubber Glove Mfg. Co. v. Goodyear Rubber Co., 128 U.S. 598, 604 (1888).

56. Lanham Act $\$ 32(1)$ (a)-(b) ; Ramirez \& Feraud Chili Co. v. Las Palmas Food Co., 146 F. Supp. 594, 599 (S.D. Cal. 1956).

57. See French Republic v. Saratoga Vichy Spring Co., 191 U.S. 427, 436 (1903); Ambrosia Chocolate Co. v. Ambrosia Cake Bakery, Inc., 165 F.2d 693, 695 (4th Cir. 1947); cf. Standard Brewery Co. v. Interboro Brewing Co., 229 Fed. 543, 545 (2d Cir. 1916) (dictum) (invalid trademark assignment estops assignor from suing assignee for infringement).

58. For the view that the competition "that counts" is "quality competition," see Schunpeter, Capitalisar, Soctalism \& Dearocract 84 (3d ed. 1950). Compare Burns, Some Lessans of the Recession, The Reporter, Dec. 11, 1958, p. 16, at 18 (product competition now more important than price competition). See also Stockrng \& Watkins, MONOPOLY \& FREE ENTERPRISE 525 \& n.29 (1951).

59. S. Rep. 3.

60. Lamib \& Kittelie, Trade Association Law \& Practice $\$ 6.10$ (1956).

61. Sugar Institute, Inc. v. United States, 297 U.S. 553, 600 (1936) ("[B] ecause sugar is a standardized commodity, there is a strong tendency to uniformity of price ...."); see C-O-Two Fire Equipment Co. v. United States, 197 F.2d 489, 493 (9th Cir. 1952) (product standardization may be evidence of price-fixing); Bond Crown \& Cork Co. v. FTC, 176 F.2d 974, 979 (4th Cir. 1949) (same); Association of Coupon Book Mfrs., 45 F.T.C. 219, 249 (1948) (same) ; Milk \& Ice Cream Can Institute v. FTC, 152 F.2d 478, 482 (7th Cir. 1946) (product standardization facilitates price-fixing); National Crepe Paper Ass'n 
producers to advertise jointly. ${ }^{62}$ When successful, current advertising techniques cause product differentiation unrelated to price or quality, and thus establish an inelastic market for the advertiser's goods. ${ }^{63}$ This result, which has been termed undesirable in the case of a single producer, ${ }^{64}$ is yet more anticompetitive when achieved by several who comprise a segment of an industry. If the members of a collective-mark association control a large percentage of the market, their combining to advertise jointly, that is, to create a demand which they alone can satisfy, could constitute an unreasonable restraint of trade under the Sherman Act. ${ }^{65}$ Nonmembers will find it increasingly difficult to compete, and

of America, 38 F.T.C. 282, 292 (1944), aff'd sub nom. Fort Howard Paper Co. v. FTC, 156 F.2d 899 (7th Cir. 1946).

Compare United States v. Synthetic Nitrogen Products Corp., 1940-43 Trade Cas. If 56170, at 626 (S.D.N.Y. 1941) (consent decree) (standardization of quantity of nitrogen in fertilizer enjoined), with Tag Mfrs. Institute v. FTC, 174 F.2d 452, 462 (1st Cir. 1949) (standardization of tags and tag products does not render lawful agreement illegal), and Crouse-Hinds Co., 46 F.T.C. 1114, 1120 (1950) (standardization of traffic signals found beneficial).

62. The Assistant Commissioner of Patents views trademarks as having three functions: fixing responsibility by indicating an article's source, protecting the public by assuring uniform quality and allowing the purchaser to obtain preferred products, and providing a "convenient handle" for advertising and demand creation. Leeds, Trademarks-Our American Concept, 46 Trademark Rep. 1451, 1453 (1956). But the collective mark performs the first two of these tasks poorly if at all. Judges and commentators have begun to recognize the significance of the third. See, e.g., Springfield Fire \& Marine Ins. Co. v. Founders' Fire \& Marine Ins. Co., 115 F. Supp. 787, 792 (N.D. Cal. 1953) ; S. C. Johnson \& Son, Inc. v. Johnson, 175 F.2d 176, 183 (2d Cir. 1949) (dissenting opinion) ; 3 C $\Lambda$ LIMANN 981-86; Brown, Advertising and the Public Interest: Legal Protection of Trade Symbols, 57 Y ALE L.J. 1165, 1185 (1948).

The term "joint advertising" has been adopted to connote advertising by a horizontal segment of an industry for joint and several benefit. The term should not be confused with "cooperative advertising" for the benefit of an entire industry. See Maple Flooring Mfrs. Ass'n v. United States, 268 U.S. 563, 566 (1925) ; Agnew, Cooperative Advertisrng By COMPETIToRs (1926). Nor with "cooperative advertising" by manufacturer and retailer. See generally Singer, Cooperative Advertising Under the Robinson-Patman Act, 26 PA. B.A.Q. 287 (1955).

63. Brown, supra note 62, at 1171-73; MAYER, Madison AvENue, USA 53 (1958) (advertising agency executive describes his profession as satisfying the client who throws two newly minted half dollars on the desk and says, "Mine is the one on the left. You prove it's better."). "[I]t is almost always the total personality of a brand rather than any trivial product difference which decides its ultimate position in the market." Remarks of advertising executive, quoted $i d$. at 58.

The techniques used are the exploitation of motivational research, see, e.g., PAckARD, Hidden Persuaders 34-35 (1957) (collective mark), the reiteration of a "unique selling point," MAYER, op. cit. stipra at 53, and the creation of a psychologically satisfying "brand image," id. at 36; see PACKARD, op. cit. supra at 48.

64. See note 9 supra.

65. See United States v. General Elec. Co., 82 F. Supp. 753, 852 (D.N.J. 1949), decree entered, 115 F. Supp. 835 (D.N.J. 1953) (urging purchasers to buy "Mazda" lamps, when latter made only by General Electric and its licensee, Westinghouse, held illegal restraint of trade). General Electric was enjoined from using the "Mazda" trademark in connection 
potential entrants unable to undertake large-scale advertising will be excluded.66 Furthermore, although joint advertising can undoubtedly effect economies of scale, it might be statutorily prohibited as an "unfair method of competition" in the market context of many small producers. ${ }^{67}$ Similarly, in an industry in which large and small producers effectively compete, increased competition resulting from the common advertising of several smaller units might not justify

with more than $1 \%$ of its sales. $115 \mathrm{~F}$. Supp. at 858 . While the demand created in General Electric was accomplished through soliciting government purchasing agents, $82 \mathrm{~F}$. Supp. at 850-52, advertising likewise acts to create demand, ChaMrerlin, Theory of Monopolistic Competition 118-20 (7th ed. 1956) ; Pease, Responstbilities of Adserican AdverTISING 22 (1958).

66. "New competition dare not enter such a field, unless it be well supported by comparable national advertising. ... Prevention of all potential competition is the natural program for maintaining a monopoly here, rather than any program of actual exclusion. 'Prevention' is cheaper and more effective than any amount of 'cure." American Tobacco Co. v. United States, 328 U.S. 781, 797 (1946).

67. See Federal Trade Commission Act $\S 5,38$ Stat. 719 (1914), as amended, 15 U.S.C. $\$ 45$ (a) (1952). Anticompetitive behavior which does not fall within the prohibition of the Sherman Act may nonetheless constitute an unfair method of competition. FTC v. Cement Institute, 333 U.S. 683, 694 (1948); Tag Mfrs. Institute v. FTC, 174 F.2d 452, 465 (1st Cir. 1949). The possibility of injured competitors combining to advertise under another collective mark does not render the technique "fair." See FTC v. R. F. Keppell \& Bro., 291 U.S. 304, 312 (1934) ; Midwest Farmers, Inc. v. United States, 64 F. Supp. 91, 97 (D. Minn. 1945). Nor would the fact of registration take the collective mark out of the FTC's jurisdiction. Charles of the Ritz Distributors Corp. v. FTC, 143 F.2d 676, 679 (2d Cir. 1944).

To issue a cease-and-desist order, the FTC must establish three prerequisites: that the behavior complained of be a method of competition in interstate commerce, that a proceeding appear to be in the public interest, and that the method of competition be unfair. FTC v. Civil Service Training Bureau, Inc., 79 F.2d 113, 114 (6th Cir. 1935). Joint advertising under a registered, collective mark may meet all three. Advertising is a method of competition, Gimbel Bros. v. FTC, 116 F.2d 578, 579 (2d Cir. 1941), and a mark must be used in interstate commerce to be registered under Lanham Act $\S 1$. If the mark is used to restrict present and potential competition, a proceeding against it would further the public interest. Dr. W. B. Caldwell, Inc. v. FTC, 111 F.2d 889, 891 (7th Cir. 1940) ; FTC v. Wallace, 75 F.2d 733 (8th Cir. 1935).

The concept of an "unfair" method of competition is flexible. FTC v. Motion Picture Advertising Serv. Co., 344 U.S. 392, 394 (1953) ; FTC v. Bunte Bros., 312 U.S. 349 (1941.). Its scope is to be defined gradually as controversies arise. FTC v. Raladam Co., 283 U.S. 643, 648 (1931) ; A. L. A. Schechter Poultry Corp. v. United States, 295 U.S. 495, 532-33 (1935) (dictum). Unfair methods of competition may sometimes consist of acts not in themselves illegal, criminal or immoral. Hastings Mfg. Co. v. FTC, 153 F.2d 253, 257 (6th Cir. 1946). The concept is broader than, although including, common-law "unfair competition," see Pep Boys-Manny, Moe \& Jack, Inc. v. FTC, 122 F.2d 158 (3d Cir. 1941), which itself is the "embodiment in law of the ancient rule of the playground-"Play fair!" 1 Nins, Unfair CoMretirion and TRADE-MaRKs $\$ 1$. (4th ed. 1947). In a market setting of many small producers, the concerted creation of demand through joint advertising under a collective mark could well be found to violate the fair-play standard because harmful to outsiders. Cf. FTC v. R. F. Keppel \& Bro., 291 U.S. 304, 313 (1934) (exploitation of nonrational tendencies of consumers can be unfair method of competition); Gamco, Inc. v. Providence Fruit \& Produce Bldg. Inc., 194 F.2d 484 (1st Cir.), cert. denied, 344 
the deleterious consequences of confronting the other small operators with yet another giant. ${ }^{68}$ If, however, oligopolists are so dominant that smaller firms must act in concert in order to survive, joint advertising could promote competition in the industry as a whole by permitting beleaguered competitors to continue as separate entities rather than engage in mergers or leave the industry. ${ }^{69}$

The possibilities of consumer confusion and anticompetitive behavior under a collective mark indicate a need for statutory reform. At a minimum, Congress should require owner-registrant associations to control the quality of their members' goods in order that consumers be able to choose preferred products. Conforming the use of collective marks with antitrust policy presents more difficult problems. The Lanham Act's protection of such marks might be withdrawn $;^{70}$ those of their functions not inconsistent with competition would then be accomplished under other sections of the statute. Groups of regional producers, for instance, could obtain protection through the certification mark-which is subject to specific statutory sanctions if abused. ${ }^{71}$ Similarly, agriculturists engaged in cooperative marketing could take advantage of the act's "related companies" provision, with its built-in requirements of quality control. ${ }^{72}$

Abolition of the collective mark would not make the sharing of a trade symbol among competitors affirmatively illegal, but would simply withdraw existing statutory encouragement in the form of the substantial benefits flowing from registration. Hence, the users of an unregistered collective mark would still en-

U.S. 817 (1952) (wholesale produce dealer forced out of marketplace which attracted all retailers).

But cf. Miller Motors, Inc. v. Ford Motor Co., 149 F. Supp. 790, 807 (M.D.N.C. 1957) (joint advertising by several Lincoln-Mercury dealers not violation of Sherman Act), aff'd, 252 F.2d 441, 447 (4th Cir. 1958) ("The plaintiff . . showed the plan for co-ordinated advertising, ... a and rested. The conclusion it wishes the court to draw is nut attainable on this record."). Joint advertising by franchised dealers of a uniform product, as in Miller, is far less offensive than joint advertising under a collective mark, especially since all dealers in an area are usually allowed to join in sponsoring advertisements. The "product" which the dealers add-unique location, services, credit terms, etc.-is not standardized; and the advertisements ordinarily carry the trade names of the individual sponsoring dealers. Moreover, the major product, be it automobile or home appliance, is already standardized because of its single source of manufacture.

68. Cf. United States v. Bethlehem Steel Corp., Trade Reg. REp. (1958 Trade Cas.) If 69189, at 74683 (S.D.N.Y. 1958).

69. Cf. American Column \& Lumber Co. v. United States, 257 U.S. 377, 413 (1921) (dissenting opinion of Brandeis, J.).

70. For the same conclusion on sharply contrasting reasoning, see Breitenfeld, Collcctive Marks-Should They Be Abolished?, 47 TRAdenark ReP. 1, 15 (1957).

71. See note 29 supra and accompanying text. Certification-mark protection would also extend to those collective marks which currently function as seals of approval. See note 22 supra. In both cases, an association would have to admit to membership all producers meeting the standards of certification. Lanham Act $\S 14$ (d).

72. Lanham Act $\S 5$. While a cooperative's marketing services may not constitute sufficient use of a mark to prevent collective-mark registration, the cooperative may readily be treated as a licensor. $C f$. ROBERT 7. 
joy common-law safeguards against unfair competition. ${ }^{73}$ Abolition would, however, render unregistrable collective marks which indicate membership in social, civic, fraternal, professional and trade organizations, and which protect group names and symbols from unauthorized exploitation. ${ }^{74}$ Consequently, if collective marks are eliminated, provision should be made for marks which designate not a source of goods or services but only membership.

Alternatively, Congress could retain collective marks and enact legislation to prevent their abuse. This legislation might require that any collective mark employed so as "to substantially lessen competition" be denied registration or, if already registered, cancelled. In this manner, "advertising mergers" would be held to Clayton Act standards. ${ }^{75}$ To ensure the proper implementation of this approach, the Patent Office should obtain the approval of the Justice Department before registering a collective mark. ${ }^{76}$ In all probability, small firms unable to meet the competition of dominant oligopolists, ${ }^{77}$ or a few firms in an industry of many small competitors, ${ }^{78}$ would be accorded the benefits of registration.

73. Gold Seal Associates, Inc. v. Gold Seal Associates, Inc., 56 F.2d 452 (S.D.N.Y. 1932); Carson v. Ury, 39 Fed. 777 (C.C.E.D. Mo. 1889) (union label); State ex rel. Seattle Bottlers Ass'n v. Flora Co., 169 Wash. 120, 13 P.2d 467 (1932).

74. See Ex parte Supreme Shrine of the Order of the White Shrine of Jerusalem, 109 U.S.P.Q. 248, 249-50 (Comm'r of Patents 1956).

75. See Clayton Act $\$ 7,38$ Stat. 731 (1914), as amended, 15 U.S.C. $\$ 18$ (1952).

76. The Justice Department is authorized by statute to give advisory opinions to heads of executive departments. Act of June $22,1870, \$ \S 4,6,16$ Stat. 162, 163, as amended, 5 U.S.C. $\$ \$ 304,30 \$$ (1952). Functionally, the proposed legislation would bind the Secretary of Commerce, acting through the Patent Office, to follow the opinions of the Justice Department with respect to the registrability of a collective mark. See Lanham Act $\$ 33(\mathrm{~b})$

(7) (mark loses statutory advantages if contrary to antitrust laws).

77. Cf. Barnes, Economic Issues in the Regulation of Acquisitions and Mergers, 14 OHı Sr. L.J. 279, 291 (1953) (merger may aid competition); Note, 43 GEo. L.J. 634, 639 (1955) (same); Note, 66 Yale L.J. 1251, 1263 (1957) (same). But cf. United States v. Bethlehem Steel Corp., Trade Reg. Rep. (1958 Trade Cas.) If 69189 (S.D.N.Y. 1958) (argument that proposed Bethlehem-Youngstown merger would increase competition with U.S. Steel held irrelevant after finding of substantial lessening of competition between the parties).

78. See Fargo Glass \& Paint Co. v. Globe Am. Corp., 201 F.2d 534 (7th Cir. 1953); V. Vivaudou, Inc. v. FTC, 54 F.2d 273, 275 (2d Cir. 1931); Temple Anthracite Co. v. FTC, 51 F.2d 656, 660 (3d Cir. 1931). 